\title{
Reestablishing the Foundations: Investigating the Theoretical and Practical Boundaries of Criminology
}

\author{
Albert Hawks, Jr. (Corresponding author) \\ Department of Sociology, University of Michigan \\ 500 S. State Street, Ann Arbor, MI 48104, USA \\ E-mail: ajhawks@umich.edu
}

Karina Mcdonald-Lopez

Department of Sociology, University of Michigan, Ann Arbor, USA

Received: Oct. 13, 2021 Accepted: Nov. 12, $2021 \quad$ Published: Nov. 30, 2021

doi:10.5296/ijssr.v10i1.19289 URL: https://doi.org/10.5296/ijssr.v10i1.19289

\begin{abstract}
Symbolic boundaries are essential to social functioning and, more narrowly, to the social functioning of academia. Yet the boundaries of the field of Criminology remain deeply ambiguous. What are the parameters of the field? What is agreed upon as foundational theory? What are the core research agendas? This lack of clarity and consensus hampers internal dialogue between interdisciplinary scholars and constrains efforts to meaningfully address critical societal ills. As such, with this review we seek to promote cohesion in the field and improve our ability to understand crime as a social phenomenon. To accomplish this, a team of researchers conducted a thorough review of criminology textbooks and top journals in the field. We first examine explicit and implicit definitions of criminology and next identify the major avenues of current research. We further highlight major avenues and oversights of research, making recommendations for further study to promote productive cohesion amongst criminologists. Finally, we combine theoretical conceptions of criminology with current research to offer a new, comprehensive definition: Criminology is the theoretically informed scientific study - and the resulting body of knowledge - of crime broadly understood as a socially constructed and embedded phenomenon as well as its causation and prevention.
\end{abstract}

Keywords: symbolic boundaries, criminological theory, agenda setting, social inequality, interdisciplinary research, literature review 


\section{Introduction}

It has long been established that boundaries are essential to social functioning and, more narrowly, to the social functioning of academia. Gieryn's original argument was that "boundary work" in the sciences served to establish epistemic authority and resolve credibility contests (Gieryn, 1983). Lamont and Molnar have similarly demonstrated that symbolic boundaries are deployed to construct meaning (2002). In the academy, then, disciplinary boundaries have served to facilitate informed, consistent research and direct methods.

Criminology — which is deeply interdisciplinary — suffers from a lack of clear disciplinary distinction (Schmalleger, 2017; Messerschmidt, 2015). As such, criminology is saturated with a loosely affiliated body of research in which there are vast differences in perspectives and theoretical frameworks regarding the scientific understanding of crime (Schmalleger, 2017). This lack of theoretical cohesion makes it difficult to produce research on crime (Kubrin, Stucky, \& Krohn, 2009). Yet crime is one of the most critical issues in social life.

Over the course of one year, our team of researchers conducted a thorough literature review of the field of criminology - exploring course textbooks and top journals - to bring clarity to the breadth of understandings of what constitutes "criminology" in the scholarly imagination. Our review is organized around two pillars: (i) definitions and theory and (ii) criminology in practice.

First, we examine definitions of criminology. We explore both explicit and implicit definitions. As part of this exploration, we were also interested in named theoretical frameworks deployed by scholars in their research. We found a wide range, with often little overlap. After synthesizing these elements, we suggest a working definition of criminology. Second, we investigate the content of criminological work. Many articles do not define criminology per se but do claim to be doing criminology in their research (or are printed in criminology journals). Broadly, we found research in this category centered on race and incarceration (Chavez, 2019; Dugan \& Chenoweth, 2020), effects of incarceration on employment (Pager, 2007; Sugie et al., 2019), crime as a social phenomenon (Gruenewald, 2015; Messerschmidt, 2015), intersectional studies of crime (Messerschmidt \& Beirne, 2015; Adler, Laufer, \& Mueller, 2018; Benson et al., 2020), and geographical and neighborhood effects (Papachristos \& Bastomski, 2018; Levi, Phillips, \& Sampson, 2020).

In considering explicit definitions, implicit definitions, theoretical genealogies, and contemporary research, we aim with this paper to promote cohesion in the field and improve our ability to understand crime as a social phenomenon. This article proceeds in three parts as follows: i) initial synthesis of existing explicit definitions, existing implicit definitions, and predominant theories, ii) review of contemporary research areas, and finally iii) we propose a synthesized definition of the field and suggest some parameters for a more coherent path forward.

\section{Methods}

We approached the research for this review in a standard manner (Webster \& Watson, 2002; 
Nordstrom \& Dackis, 2011; Milkoreit et al., 2016). We first specified the boundaries of our inclusion criteria as all studies which include mention of the keyword "criminology" in the following top-tiered peer-reviewed journals: Social Forces, Social Issues, American Journal of Sociology, Annual Sociological Review, Social Psychology, Journal of Social Psychology, Theoretical Criminology, Criminology, and Journal of Research in Crime and Delinquency. addition, we included any academic textbook currently in use in higher education criminology courses. This was limited to articles that at a minimum were aiming to perform criminological research, between 1990 (allowing for "snowballing" beyond this timeframe) and present. This included "sparse" mentions, so long as the article was situated as belonging to the field.

Our team conducted searches in the above-mentioned journals, using keywords related to crime and criminology. After screening the abstracts of all identified articles, some were excluded because they lacked either explicit or implicit definitions of criminology, or any discussion of theoretical geologies of criminology.

We also contacted criminology instructors at any higher education institution in the United States that had an active criminology department and requested a current (2020) syllabus. Using these syllabi, we identified textbooks in current use, located these textbooks, and reviewed them for relevant content.

We read each source to identify the primary aim(s) of the text and the degree to which it conformed to the purpose of our review-to identify: (a) explicit definitions, (b) implicit definitions, (c) named theoretical frameworks, and (d) research subject. We summarized these findings under thematic headings in a table shared within our research team. After data was collected, we synthesized the material, identifying similarities and differences across the various studies. This review is not intended to be exhaustive in the sense of representing every unique mention and every specific avenue of relevant study. While we surveyed many more articles than cited, our intention here is to offer a representative sample of trends that emerged.

\section{Defining Criminology}

Criminology is seen as an independent discipline, widely acknowledged as drawing on multiple sister disciplines and methodologies-including sociology, biology, psychology, economics, and ecology (Frailing \& Harper, 2016). But what exactly is defined as "criminology" is unclear. There is profound disagreement on a definition proper (Hagan, 1990) and differences in terms of causation (Cullen \& Agnew, 2003).

Despite disagreement, there are some widely used definitions and core tenets that appear across textbooks. Several texts use some version of Sutherland and Cressey's definition of criminology as, "[1] the body of knowledge treating crime [2] as a social phenomenon" (Schmallegger, 2017; Siegle, 2015; Adler, Laufer, \& Mueller, 2018; Akers, 1999). Still other texts use a variation of the following formulation: Criminology is the [3] scientific study of criminal behavior, [4] including its causation and prevention (Cullen \& Agnew, 2003; Schram \& Tibbetts, 2018; Hagan, 1990; Rennison \& Dodge, 2016; Adler, Laufer, \& Mueller, 
2018; Frailing \& Harper, 2016; Siegle, 2015; Schmalleger, 2017; Siegle, 2019). Most textbooks also emphasize that criminology is [5] a theory-driven study of crime (Kubrin, Stucky, \& Krohn, 2009; Lilly, Cullen, \& Ball, 1995; Cullen \& Agnew, 2003; Akers, 1999; Hagan, 1990).

We find that few journal articles deal directly with the notion of criminology as a field except to note the limiting effects having a field can create. Hillyard (2014), for example, notes that a field such as criminology "inevitably" distorts the overall picture of harm. Relatedly, Sweeny (2014) discusses the data limitations on any study of crime. Krohn, discussing Agnew's unified theory of crime incidentally highlights that part of the challenge of defining criminology requires us to also develop a concept of what is [6] worthy to be discussed as crime (Agnew, 2011; Krohn, 2012) (Note 1). In other words, most journal articles that explore the field of criminology tend to emphasize the issue of unit of analysis.

Despite not explicitly defining criminology, many journal articles do reference "criminology" or "criminologists" in a way that treats the field as independent (Sykes, 2019; Greene, 2019; Muller, 2018; Harding et al., 2018; King \& Johnson, 2016; Western et al., 2015; Campbell \& Schoenfeld, 2013; Muller, 2012; De Young, 2012; Carlson, 2019). In the same vein, many studies also use explicitly "criminological" journals in their references, even if the article itself does not claim the field (Bell, 2020; Carlson, 2019; Mobasseri, 2019; Slade, 2018; Kramer, 2016; Walker, 2016).

Finally, numerous book reviews identify an original work as being important to the field of criminology (Flores, 2020; Sykes, 2019; Jones, 2018; Slade, 2018; Gruenewald, 2015; Jackson, 2015; Hillyard, 2014; Warner, 2014; Sweeny, 2014; Washington, 2014; Nurse, 2014; Abrahamson, 2013; Westbrook, 2013; Krohn, 2012; Levi, 2012; Garot, 2012; Rosenfeld, 2011; Zuberi, 2011; Ocampo, 2011; Matsueda, 2011). For example, in a book review of Byfield's Savage Portrayals (2013), Gruenewald argued Byfield's work offered important lessons for criminology about the black feminist and intersectional perspectives (Gruenewald, 2015).

As there is not an explicit definition of criminology established, there is no unified theoretical foundation. This became clear as our review of the literature developed. While many undergraduate textbooks may offer a version of chronological origin, the said origin seems to hold little to no power over how criminologists conceptualize themselves as scholars. In reality, most scholars develop their own theoretical frames within highly specific silos (Note 2). For example, critical criminological insights almost never cross into mainstream criminology.

In sum, while there is no absolute consensus, we think a concise definition of criminology should include each of the six elements from the above-cited scholarship. We now look at the practical application of criminology in contemporary the literature before proposing a synthesized definition.

\section{Criminology in Practice}

Despite the lack of an agreed-upon definition of criminology, there exists a body of research 
that self-identifies as criminological. As such, a second critical avenue for exploring the intellectual boundaries of the field lies in exploring the implicit definitions offered by the actual contemporary practice of criminological research. In other words: what does it mean to "do" criminology?

We've organized the following section under four broad scholarship areas: (a) crime and social identities; (b) the relationship between criminal justice and social inequality; (c) studies regarding incarceration and its social context; and (d) narratives about crime and their neighborhood context.

\subsection{Crime and Social Identities}

A dominant theme within the literature is exploring the relationship between social identities and crime to understand criminalization and offending.

\subsubsection{Race and Crime}

First, there is a body of literature on the relationship between race and victimization of crime. For instance, Chavez (2019) explores the connection between present day anti-blackness and Afro-pessimism, and how that condition of society has contributed to racial violence. Along the same lines, Dugan and Chenoweth (2020) analyze Blalock's (1967) intergroup/minority threat theory in context of political threat and hate crimes, generating two sub-theories: (i) the political threat hypothesis which suggests positive government attention towards groups leads to more hate crime against them, and (ii) the emboldenment hypothesis, which suggests that negative government attention towards specific groups leads to more hate crime violence against them.

\subsubsection{Gender and Crime}

A number of studies identify ways in which gender norms, such as masculinity, influence violent behavior from adolescent bullying to sexual assault (Flores, 2020; Green, 2019; Westbrook, 2013). These demonstrations of hyper masculinity extend to various subgroups as well (Panfil, 2020). For example, Green (2019) finds that LGBTQ gang members work to demonstrate their masculinity through crime as a way to earn respect and protect their reputation within the gang space. Some individuals use sexuality to claim subjecthood, and in doing so commit sexually violent acts (Westbrook, 2013).

There is also a large body of literature which examines how women's criminal experiences-with prostitution and drug use specifically-are colored by the hyper-masculine context in which their actions occur (Jackson, 2015). Ellis (2020) focuses on the institution of religion and its effect on incarcerated women, specifically how protestant narratives regulate women's emotional and sexual behaviors which act as rules for incarcerated women that support state authority and control. Kreager similarly examines the gendered nature of prison organization, examining how gender shapes the informal structure of prison organization for both men and women (Kreger et al., 2020). Alternatively, male victims of sexual and gender-based violence are often excluded from international criminal justice (Ullrich, 2019). Finally taking a more abstract lens, Chesney-Lind examines racism 
and sexisim in the field of criminology itself, examining the race and gender biases within the field of criminology and the ways scholars approach crime (Chesney-Lind, 2020).

\subsubsection{Complex Intersections and Crime}

Given the above, it's not surprising to note that there is a substantial body of literature exploring the relationship between multiple social identities and their co-relationship to crime. The overarching point scholars wish to emphasize is that in order to understand crime and offending, it is important to examine how identities and overlapping identities contribute to criminalization (Tran \& Spivakovsky, 2019). This is most pronounced in scholarship regarding the relationship between racial and economic inequality (Barkan, 2018). Social inequality, racism, and poverty are broadly seen as the core series of variables leading to crime (Schmalleger, 2017).

Broadly, scholars have recognized that the core reason for higher participation in crime among ethnic minorities - specifically, African Americans - is racial economic inequality (Messerschmidt \& Beirne, 2015). Indeed, the relationship is so pronounced that some in criminology even explicitly define racial inequality as rooted in economic inequality (Adler, Laufer, \& Mueller, 2018). On the other side of this coin, scholars have explored economic advantage amongst whites as predictors of engagement in white-collar crime (Sohoni \& Rorie, 2019), though in recent years there has also been an increase in non-White participation in white-collar crime and convictions (Benson et al., 2020).

Lastly, there has been some research on immigration law through a criminological lens, largely discussing the value (or lack thereof) of applying criminological insights to immigration issues (Soliman, 2019; Kemp, 2019; Gashi, Pedersen, \& Ugelvik, 2019).

\subsection{Criminal Justice, Social Inequality, and Incarceration}

The most prevalent theme in recent criminological research is the criminal justice system, specifically the intersection between the criminal justice system and social inequality. Introductory texts assert the deep connection between criminology and criminal justice with confidence (Schram \& Tibbetts, 2018; Siegle, 2015). One even suggests that the causes of crime are unsolvable, making crime prevention and justice the only tenable avenues of research (Messerschmidt \& Bierne, 2015). From work on the intersection of the criminal justice system and social inequality, we know that marginalized groups are far more likely to face imprisonment, especially in contexts where their socioeconomic resources are unusually low (such as labor demand) and where control over criminal justice is dominated by singular hegemonies (Muller, 2018). Moreover, while there is a long history of racial disparity in the United States, the extreme proliferation of incarceration in the U.S. in recent years has driven the disparate impact of the penal system to new heights (Muller, 2012). This has also been explored in the context of disability and ableism (Thorneycroft \& Asquith, 2019). Recent scholarship on this intersection has followed a few key subfoci.

\subsubsection{Race and Incarceration}

One focus of criminological research is that which focuses on race and incarceration. 
Scholarship within this vein explores the effects of racial status on sentencing and incarceration rates. Broadly scholars find that racism within the criminal justice system is related to an increased likelihood of incarceration, harsher sentences, and wrongful convictions for racial minorities (Bell, 2020; Muller, 2018; Monk, 2015; Gruenewald, 2015). Empirical evidence suggests that these racial disparities exist across virtually every stage of the criminal justice system-from policing, to adjudication, supervision, and corrections (Goodman, 2014). For instance, Omori and Peterson analyze criminal history, charging and pretrial detention, finding strong inequalities between white non-Latinos and Black Latinos in legal case factors (2020). Further, the decisions of actors within the criminal justice system are also influenced by the social climates in which they are located, and these social climates can also contribute to deepening racial disparities within the criminal justice system. For example, Baumer (2013) examines how the decisions of prosecutors, judges and juries are influenced by the political and religious contexts in which they are situated - such that religious and political conservatism, racial prejudice related to fear of crime, and public sentiment about harsh sentencing influence criminal adjudication.

There is no shortage of criminological studies which examine how racial inequalities are related to incarceration specifically (see for example Matsueda, 2011; King \& Johnson, 2016; Harding et al., 2018). Though this section is but a limited look into this body of literature, the general consensus within the literature is that blacks and Hispanics are incarcerated at a rate that is significantly greater than the rate of imprisonment of whites. This evidence of racial disparities in U.S. punishment practices has led to a wealth of criminological literature on the expanding prison system for black and Hispanic men. One such study conducted by King and Johnson (2016), finds that not only does race matter for incarceration rates, but color does as well. They find that for dark-skinned blacks, the odds of incarceration are twice as high compared to lighter skinned blacks (King \& Johnson, 2016). Thus, where blacks are disadvantaged regarding incarceration rates relative to whites, dark-skinned blacks are even further so. In addition to examining these racial inequalities, criminologists also explore how these inequalities have effects beyond the criminal justice system-such as the community-level consequences of removing thousands of working-age black men from the labor market throughout their life course (Harding et al., 2018).

\subsubsection{Post-Incarceration Inequality}

A wide range of research focuses on the penal system and its relationship to enforcing structural inequality. Walker has demonstrated the powerful effect racialization internal to prisons has on pre-existing racial tensions outside of prisons and described it as a "power engine of social inequality" (Walker, 2016, 2014). These ongoing biases further degrade the treatment of urban youth of color, deepening the criminalization of race (Garot, 2012). Further, reform techniques within prisons, especially among youth, is demonstrably harmful and by extension has disproportionate long-term effects on urban youth of color (Sykes, 2019). Researchers have also explored the unequal impact stigma has on prisoners after they leave the penal system. Kramer has demonstrated that whites do not lose racial privilege as a result of going to jail (while people of color do) and, conversely, that minority groups increase their "passing" for whiteness in social life by avoiding incarceration (Kramer, 2016). 


\subsubsection{Incarceration and Employment}

Employment has already been mentioned in the above section as a specific avenue for intersectional inequality. But the relationship between incarceration and employment specifically has been the focus of much scholarship. The general connection between socio-economic status and criminality is widely established and that being incarcerated has a dramatic impact on economic outcomes (Reich \& Prins, 2015). Obviously, while a person is incarcerated, they are removed from the labor force, however the effects of incarceration persist after their release as well, as the stigma of their criminal record and perceived risk of future criminal conduct narrows employment opportunities (Sugie et al., 2019; Pager, 2007). We know that the instability and strain of "foraging" employment dramatically aggravate the circumstances leading to crime (Sugie, 2018). Relatedly, the overall job market impacts both the crime rate and family life and single motherhood (Vogel, Thompson, \& Messner, 2019).

The economic impact of a criminal record is, as mentioned, disproportionate in its impact. Labor discrimination and low demand for marginalized groups is a major driver to criminal activity (Jones, 2018). Further, systematic inequality in the "front end" of the penal system disproportionately impacts black communities by dramatically removing black men from the labor market (Harding et al., 2018). Finally, black men with a criminal record face a dramatically decreased call back rate when compared to other ethnicities (Mobasseri, 2019).

\subsubsection{Policing and Inequality}

Many scholars explore the specific relationship between policing, police violence, and social inequality (most often in the context of race) (Flores, 2020; Bell, 2020; Jacobs, 2019; Nurse, 2014). Most often this is explored in the context of race, which has received attention especially in recent times because of the Black Lives Matter (BLM) movement (Gaston et al., 2020).

For example, how legal cynicism in racially segregated neighborhoods is directly related to interactions between police officers and citizens and grounded in collective historical cynicism of police abuse of power (McCarthy et al., 2020). Scholarship has shown penal institution preferences serve at a micro-level to reproduce residential segregation (Bell, 2020). Police use of deadly force is dramatically disproportionate by race (Jacobs, 2019).

\subsubsection{Desistance and Recidivism}

The twin concepts of desistance and recidivism collectively represent a major research area. The concept of desistance - an individual's cessation of criminal activity of their own power-has gradually developed independently of research on control. Recent research has focused on marginalized groups as a unique window into desistance. For example, Fredrikkson and Gålnander focus on the specific obstacles and circumstances women encounter in their attempt to desist deviance (Fredrikkson \& Galnander, 2020). Alternatively, Panfil focuses on desistance or persistence of gay gang members in heteronormative gang culture (Panfil, 2020).

Unsurprisingly, questions of life-after-incarceration remain one of the most predominant. 
Recent work by Hickert analyzes processes of criminal reoffending and turning points in criminal identity as they relate to social and structural challenges faced by criminals post incarceration. Wildeman and Anderson explore the relationship between prisoner reentry, employment, and disciplinary segregation in the context of restrictive housing (Wildeman \& Anderson, 2020).

Somewhat related to both above subjects, recent scholarship has become interested in the substantial decline in youth offenses. Baumer et al. tries to determine why youth offending has declined substantially by studying behaviors such as commitment to school, community involvement, parental supervision, etc. Specifically mentions routine activity theory (Baumer, 2020). Widowson et al found that younger cohabiting partnership substantially altered behavior in such a way as to discourage criminal offense (with variability) (Widowson et al., 2021). Perhaps reflecting a similar variable from a sociological perspective, Bucci and Staff look at the relationship between family dynamics, puberty, and adolescent crime, finding family networks have substantial impact (Bucci \& Staff, 2020). Further, Ragan found that the largest influence on drinking and smoking amongst adolescents is not peers generally, but homophily (Ragan, 2020). Finally, Buchanan and Krohn found that, in the context of gang involvement, arrests only negatively deterred future behavior among non-affiliated youth (Buchanan \& Krohn, 2019). In sum, youth desistance is highly dependent on homophily and deep social networks.

Drawing broadly on this research, scholars tend to recommend more rehabilitative efforts to increase desistance, specifically aimed at "therapeutic surveillance" and providing support for inmates rather than additional punishment and exclusion (Brangan, 2019; Gray \& Smith, 2019; Mazur \& Sztuka, 2019). Though probation and community supervision programs are often seen by policy makers as rehabilitative efforts, some scholars argue that in fact the expansion of programs such as these actually "widen the net" of punishment possibilities, in effect becoming a further extension of the penal system (Western et al., 2015; Phelps, 2018). Rather than being therapeutic surveillance, probation has the potential to impose more serious punishment measures on low-level cases, and expose probationers to fines and fees, and potentially result in incarceration via violations (Phelps, 2018; Goodman, 2014; Bell, 2020).

\subsubsection{Organizations and Working for the Carceral State}

While most studies tended to cover the unequal deployment of the justice system and its impact on larger society, a select few also attended to the organizational character of the justice system itself. Haggerty and Bucerius (2020), for example, examine how correctional officers utilize discretion towards incarcerated people and the various factors that contribute to enforcement (or non-enforcement) of rules. Wolfe and Lawson (2020) "flip the script" a bit and analyze the concept of justice in the work environment for employees of the justice system, applying organizational justice theory.

\subsection{Narratives and Neighborhoods}

\subsubsection{Media, Race, and Crime}

Much scholarship has studied the way media portrayals of race, class, and gender shape the 
judicial system. In particular, the media portrayal of crime has a strong impact on how crime is viewed by the public and how individuals are tried (Gruenewald, 2015). Political rhetoric has been demonstrated to reshape prison staff views of inmates and their essential natures, especially regarding black women who have been increasingly incarcerated (Nurse, 2014). This rhetoric is often driven by two factors: (i) the desire to be seen as "tough on crime" for electoral purposes, and (ii) as a proxy for explicit race politics (Campbell \& Schoenfeld, 2013). In this context, extremely punitive crime policy is often developed with strong implicit bias. To that end, a recent study of the 2016 election examined the tensions between the symbolic role of police in American society and black deaths at the hands of American police and its role fueling voter turnout (Drakulich et al., 2020).

\subsubsection{Fear of Crime}

In many ways directly connected to media representation and political rhetoric, much criminological research is aimed at understanding fear of crime, or more specifically fear of victimization (for a discussion of fear of victimization see Rountree \& Land, 1996; LaGrange \& Ferraro, 1989; Melde et al., 2019). One such example is work by Helena Menih which examines the relationship between female homelseeness and crime victimization. In this instance, fear of crime is a consequence of gender inequality, and women are forced to negotiate and redefine their positions in this space in response to their risk assessment of victimization (2020). Other scholars examine how crime myths are created and perpetuated and how those myths relate to fear of crime, for instance how images of crime are constructed by the media with implications for spreading fear (Messerschmidt, 2015). These crime myths are problematic in that they often create a specific image of a criminal and shape public perception of crime in ways unsupported by data. To illuminate this point, Haner and colleagues examine how Muslims and migrants are often criminalized due to stereotypes and media bias fueling fear of terriorism and immigrant crime (2020). In addition to media involvement, globalization and changing demographics in the U.S. also work to fuel fear of terrorism (Abrahamson, 2013). The fear of crime even impacts the efficiency of rehabilitation after release, with strong evidence that the efficiency of parole is threatened in societies marked by high fear of crime (Barry, 2019).

\subsubsection{Crime and Place Research in the Chicago School}

Of course, fear of crime does not solely arise from civil discourse, but also the literal proximity of crime which is itself deeply connected to issues of space and place. Unsurprisingly, research focused on space, neighborhoods, and networks remains important (Levi, 2012; Legewie, 2016; Weisburd, 2016; Warner, 2014). There is a strong correlation between the spatial clustering of crime in cities and other social problems, such as economic disadvantage and health outcomes (Papachristos \& Bastomski, 2018; Levi, Phillips, \& Sampson, 2020). Solidarity, largely driven by space, fuels and guides criminal activity. Broadly, we know that solidarity is connected to intergroup violence (Legewie, 2016) and more specifically that gang identity and location are highly correlated with violence (Lopez-Aguado \& Walker, 2019). Alternatively, isolation increases the likelihood of participating in white-collar crime (Sohoni \& Rorie, 2019). In other words, recent scholarship 
has essentially confirmed long-held theories of space and crime.

\section{Discussion}

We have now examined the existing theoretical definition of criminology as well as the practical expressions of criminology. Comparing the two proves revealing. First, and most generally, the various components in our explicit definition are consistently present and thus validated in the literature. For example, virtually all afore-mentioned articles carefully develop a theoretical framework. Alternatively, each of the individual foci are explicitly social in nature, confirming the approach to crime as a social phenomenon.

That said, there are important caveats. First, while it is true that the field is deeply theoretical and draws from a larger knowledge base, it is important to note the almost "siloed" nature of this body of knowledge and theory. Generally speaking, criminologists appear to exist in separate spheres that are defined by specific subjects of study and largely draw from and build on works in this limited space. Similarly, while all articles deploy scientific methods broadly described the specific approaches and logics behind methodology are widely disparate. Finally, while it is true that work is still being done regularly on causation (economic context, for example), the same does not appear to hold true for prevention beyond critiquing existing preventative measures.

Moving beyond the existing core definitional elements, there also appear to be a couple key elements that should be thought of as a part of criminology, if not outright added to the explicit definition. There is a strong consistent emphasis on the intersectionality of social identity and positionality with crime. This manifests as studies of disparate impact, application, and identification of crime, among other things. While this has not necessarily been true of criminology throughout its entire history, it is worth noting as a major contemporary feature. Second, the literature consistently treats crime not just as a social phenomenon, but more pointedly as a social construct. In other words, not only does crime have a social context, but it seems broadly understood that the idea of crime itself is socially constructed. We would go so far as to recommend changing this word in the definition.

With that modification, criminology may thus be defined as:

Criminology is the theoretically informed scientific study - and the resulting body of knowledge - of crime broadly understood as a socially constructed and embedded phenomenon as well as its causation and prevention.

This definition captures both the ideal, theoretical nature of the field and the actual research performed by contemporary criminologists.

\section{A Path Forward}

Our findings here, especially regarding the theoretical genealogies behind criminological research, raise follow up questions. For example, while we know that authors refer to criminology as an independent subject, we don't know how far this understanding goes. It would be fruitful and instructive to interview criminological scholars to better understand how they actively conceptualize the field. In terms of theoretical genealogies, some form of 
mixed methods analysis would likely be instructive. We know, for example, that several scholars reference racial threat theory. It would be beneficial in the future to analyze if their references were endorsing or merely acknowledging. This could help in our aim to develop greater theoretical consensus. Finally, the discipline would likely benefit from a more thorough review of the specific subjects involved. We, for example, are conducting a follow up literature review on serial homicide (McDonald-Lopez \& Hawks, in progress).

Beyond ways to expand this specific review, the process has highlighted a few critical areas for scholars to develop. Most obviously - and arguably pressingly - there truly is not a unified body of information that all criminologists agree upon. Reaching a broader, more stable consensus is in our view a critical goal. In many ways, the "field" feels much more like a series of separate fields connected only by the concept of illegality. Integrated theory must be a core agenda item (Schmalleger, 2017). Agnew offered important ideas about the unifying assumptions of criminology even as he acknowledged a tendency to ignore efforts on behalf of unity (Agnew 2011)). His work, and the general call, deserve an answer. This necessarily begins with finding the most researched trends and themes. We've begun this process here, though much work remains. Our definition offers a step. Continued discussion is very welcome.

More specifically, it is abundantly clear that criminology is an interdisciplinary field in the sense that it benefits from scholars in a wide variety of fields. For criminology to be truly distinctive (and not simply a glorified conference), it must better clarify the relationship between the various layers of variables introduced by different disciplines. For example, how, when, and to what extent are biological factors shaped by sociological ones? Is there an ordering? Are some factors a priori?

As a general note, there has been little contemporary positive definitional work. What constitutes "crime" in any given study is highly inconsistent and largely beholden to the author's agenda. Definitions are always highly contested and inevitably flawed. This does not mean the process of striving for more universal concepts is meaningless. If anything, the growing silos in criminology demonstrate passively the importance of cohesion.

Cohesion in the discipline is not only theoretically beneficial, but there is also a policy payoff as well. Criminal justice policies would benefit from scholarly influence, both in the way of informing punishment practices and reformation efforts. Yet it is difficult to speak with any real authority on these pressing social issues without an agreed upon definition of "criminology" or unified field of study. Moreover, in our review of the literature we found that there has been little recent scholarship on the prevention of crime broadly speaking, an area which, given the current state of policing in the U.S., could surely benefit from criminological contribution.

This review aimed to develop a contemporary definition of criminology alongside a survey of core theoretical frameworks and areas of research. Our aim has been to offer a cohesive foundation from which future scholarship can develop a more unified core for the field. This unity will strengthen criminology's interdisciplinary work and provide a more credible platform for meaningful progress in theoretical understandings of social processes related to 
crime and applied policy solutions in criminal justice reform.

\section{Acknowledgments}

The authors would like to thank Shoshana Shapiro and Fatma Muge Gocek for invaluable feedback during the review process, and our wonderful team of research assistants: Shannon Hickey, Tatum Kleis, Katherine Hasted, Katherine Beekman, and Samantha Johnson. This material is based upon work supported by the National Science Foundation under Grant No. DGE 1841052. Any opinions, findings, and conclusions or recommendations expressed in this material are those of the author(s) and do not necessarily reflect the views of the National Science Foundation.

\section{References}

Abrahamson, M. (May 2013). Globalization, Fear, and Insecurity: The Challenges for Cities North and South. By Sophie Body-Gendrot. New York: Palgrave Macmillan, 2012. Pp. xx+213. American Journal of Sociology, 118(6), 1717-1718. https://doi.org/10.1086/669614

Adler, F., Laufer, W. S., \& Gerhard, W. O. (2018). Criminology (9th ed.). New York, NY: McGraw-Hill.

Agnew, R. (2012). Toward a unified criminology: Integrating assumptions about crime, people, and society. New York University Press.

Ahoran-Gutman, M. (2019). Border disorder: On urban boundary work and crime in the divided city. Theoretical Criminology, 25(1), 127-148. https://doi.org/10.1177/1362480619871623

Akers, R. L. (1999). Criminological Theories: Introduction and Evaluation. New York, NY: Routledge.

Barkan, S. (2018). Criminology: A Sociological Understanding (7th ed.). New York, NY: Pearson Education Inc.

Barry, M. (2019). 'Walking on ice': The future of parole in a risk-obsessed society. Theoretical Criminology, 25(2), 325-342. https://doi.org/10.1177/1362480619880555

Baumer, E. P., \& Kimberly, H. M. (July 2013). Social Organization, Collective Sentiment, and Legal Sanctions in Murder Cases. American Journal of Sociology, 119(1), 131-182. https://doi.org/10.1086/672082

Baumer, E., Kelsey, C., \& Luo, L. Y. (December 2020). The contemporary transformation of american youth: An analysis of change in the prevalence of delinquency, 1991-2015. Criminology, 59(1), 109-136. https://doi.org/10.1111/1745-9125.12264

Bell, M. C. (January 2020). Located Institutions: Neighborhood Frames, Residential Preferences, and the Case of Policing. American Journal of Sociology, 125(4), 917-973. https://doi.org/10.1086/708004

Botoeva, G. (2019). Multiple narratives of il/legality and im/morality: The case of small-scale 
hashish harvesting in Kyrgyzstan. Theoretical Criminology, 25(2), 268-283. https://doi.org/10.1177/1362480619880344

Brangan, L. (2019). Pastoral penalty in 1970s Ireland: Addressing the pains of imprisonment. Theoretical Criminology, 25(1), 44-65. https://doi.org/10.1177/1362480619843295

Brown-Saracino, J. (2015). How Places Shape Identity: The Origins of Distinctive LBQ Identities in Four Small U.S. Cities. American Journal of Sociology, 121(2), 1-63. https://doi.org/10.1086/682066

Burt, C. H., Ronald, L. S., \& Frederick, X. G. (2012). Racial Discrimination, Ethnic-Racial Socialization, and Crime: A Micro-Sociological Model of Risk and Resilience. American Sociological Review, 77(4), 648-677. https://doi.org/10.1177/0003122412448648

Campbell, M. C., \& Heather, S. (March 2013). The Transformation of America's Penal Order: A Historicized Political Sociology of Punishment. American Journal of Sociology, 118(5), 1375-1423. https://doi.org/10.1086/669506

Carlson, J. (November 2019). Revisiting the Weberian Presumption: Gun Militarism, Gun Populism, and the Racial Politics of Legitimate Violence in Policing. American Journal of Sociology, 125(3), 633-682. https://doi.org/10.1086/707609

Chavez, E. K. (2019). Intrusions of violence: Afro-pessimism and reading social death beyond solitary confinement. Theoretical Criminology, 25(1), 3-22. https://doi.org/10.1177/1362480619846132

Chesney-Lind, M. (May 2020). Feminist criminology in an era is misogyny. Criminology, 58(3), 407-422. https://doi.org/10.1111/1745-9125.12247

Cullen, F. T., \& Robert, A. (2003). Criminological Theory: Past to Present. Los Angeles, CA: Roxbury Publishing Company.

De Young, M. (Mar 2012). Sex Fiends, Perverts, and Pedophiles: Understanding Sex Crime Policy in America by Chrysanthi S. Leon. American Journal of Sociology, 117(5), 1531-1533. https://doi.org/10.1086/664487

Drakulich, K., Wozniak, K. H., Hagan, J., \& Johnson, D. (2020). Race and policing in the 2016 presidential election: Black lives matter, the police, and dog whistle politics. Criminology, 58(2), 370-402. https://doi.org/10.1111/1745-9125.12239

Ellis, R. (Sept 2020). Redemption and reproach: Religion and carceral control in action among women in prison. Criminology, 58(4), 747-772. https://doi.org/10.1111/1745-9125.12258

Ferrell, J., Keith, H., \& Jock, Y. (2008). Cultural Criminology: An Invitation. Thousand Oaks, CA: SAGE Publications.

Flores, E. O. (January 2020). The Chosen Ones: Black Men and the Politics of Redemption. By Nikki Jones. Oakland: University of California Press, 2018. American Journal of Sociology, 125(4), 1147-1149. https://doi.org/10.1086/706635 


\section{Macrothink}

International Journal of Social Science Research

ISSN 2327-5510

2022, Vol. 10, No. 1

Frailing, K., \& Dee, W. H. (2016). Fundamentals of Criminology: New Dimensions (2nd ed.). Durham, NC: Carolina Academic Press.

Fredrikkson, T., \& Robin, G. (May 2020). Fearful futures and haunting histories in women's desistance from crime: A longitudinal study of desistance as an uncanny process. Criminology, 58(4), 599-618. https://doi.org/10.1111/1745-9125.12250

Garot, R. (Mar 2012). Punished: Policing the Lives of Black and Latino Boys by Victor M. Rios. American Journal of Sociology, 117(5), 1529-1531. https://doi.org/10.1086/664486

Gashi, L., Pedersen, W., \& Thomas, U. (2019). The pains of detainment: Experience of time and coping strategies at immigration detention centres. Theoretical Criminology, 25(1), 88-106. https://doi.org/10.1177/1362480619855989

Gaston, S., Rod, K. B., \& Leigh, S. G. (June 2020). Are Minorities Subjected to, or Insulated from, Racialized Policing in Majority-minority Community Contexts? The British Journal of Criminology, 60(6), 1416-1437. https://doi.org/10.1093/bjc/azaa038

Gieryn, T. F. (1983). Boundary-Work and the Demarcation of Science from Non-Science: Strains and Interests in Professional Ideologies of Scientists. American Sociological Review, 48(6), 781-795. https://doi.org/10.2307/2095325

Goodman, P. (Sept 2014). Race in California's Prison Fire Camps for Men: Prison Politics, Space, and the Racialization of Everyday Life. American Journal of Sociology, 120(3), 352-394. https://doi.org/10.1086/678303

Gray, P., \& Roger, S. (2019). Shifting sands: The reconfiguration of neoliberal youth penalty. Theoretical Criminology, 25(2), 304-324. https://doi.org/10.1177/1362480619872262

Greene, T. (March 2019). The Gang's All Queer: The Lives of Gay Gang Members. By Vanessa R. Panfil. New York: New York University Press, 2017. Pp. xiv+289. \$89.00 (cloth); $\$ 28.00$ (paper). American Journal of Sociology, 124(5), 1627-1629. https://doi.org/10.1086/702529

Gruenewald, J. (2015). Savage Portrayals: Race, Media, and the Central Park Jogger Story by Byfield. American Journal of Sociology, 121(2), 611-613. https://doi.org/10.1086/682203

Hagan, F. E. (1990). Intro to Criminology: Theories, Methods, and Criminal Behavior. Chicago, IL: Nelson-Hall Inc.

Haggerty, K. D., \& Sandra, M. B. (Nov 2020). Picking battles: Correctional officers, rules, and discretion in prison. Criminology, 59(1), 137-157. https://doi.org/10.1111/1745-9125.12263

Haner, M., Melissa, M. S., Justin, T. P., \& Francis, T. C. (November 2020). Safe Haven or Dangerous Place? Stereotype Amplification and Americans' Perceived Risk of Terrorism, Violent Street Crime, and Mass Shootings. The British Journal of Criminology, 60(6), 1606-1626. https://doi.org/10.1093/bjc/azaa045

Harding, D. J., Jeffery, D. M., Anh, P. N., \& Shawn, D. B. (June 2018). Imprisonment and 
Labor Market Outcomes: Evidence from a Natural Experiment. American Journal of Sociology, 124(1), 49-110. https://doi.org/10.1086/697507

Heimer, K., \& Ross, L. M. (1994). Role-Taking, Role Commitment, and Delinquency: A Theory of Differential Social Control. American Sociological Review, 59(3), 365. https://doi.org/10.2307/2095939

Hickert, A., Shawn, B., Paul, N., \& Anja, J. E. D. (November 2020). Confinement as a two-stage turning point: Do changes in identity or social structure predict subsequent changes in criminal activity? Criminology, 59(1), 73-108. https://doi.org/10.1111/1745-9125.12262

Hillyard, P. (November 2014). Why We Harm. By Lois Presser. New Brunswick, N.J.: Rutgers University Press, 2013. Pp. xii+163. \$75.00 (cloth) \$24.95 (paper). American Journal of Sociology, 120(3), 994-996. https://doi.org/10.1086/678439

Hwang, J., \& Robert, J. S. (2014). Divergent Pathways of Gentrification: Racial Inequality and the Social Order of Renewal in Chicago Neighborhoods. American Sociological Review, 79(4), 726-751. https://doi.org/10.1177/0003122414535774

Jackson, C. (May 2015). Leaving Prostitution: Getting Out and Staying Out of Sex Work. By Sharon S. Oselin. New York: New York University Press, 2014. Pp. xii+207. \$75.00 (cloth); $\$ 23.00$ (paper). American Journal of Sociology, 120(6), 1866-1868. https://doi.org/10.1086/680514

Jacobs, M. D. (July 2019). Mirage of Police Reform: Procedural Justice and Police Legitimacy. By Robert E. Worden and Sarah J. McLean. Oakland: University of California Press, 2017. Pp. xii+254. \$34.95. American Journal of Sociology, 125(1), 321-323. https://doi.org/10.1086/703814

Jensen, G. F. (1994). New Directions in Criminological Theory: Advances in Criminological Theory. Social Forces, 72(3), 913-914. https://doi.org/10.2307/2579795

Jones, A. (November 2019). Women of the Street: How the Criminal Justice-Social Services Alliance Fails Women in Prostitution. By Susan Dewey and Tonia St. Germain. New York: New York University Press, 2016. Pp. ix +274 . \$89.00 (cloth); \$30.00 (paper). American Journal of Sociology, 124(3), 991-993. https://doi.org/10.1086/701665

Kemp, T. (2019). Solidarity in spaces of 'care and custody': The hospitality politics of immigration detention visiting. Theoretical Criminology, 25(2), 249-267. https://doi.org/10.1177/1362480619887163

King, R. D., \& Brian, D. J. (July 2016). A Punishing Look: Skin Tone and Afrocentric Features in the Halls of Justice. American Journal of Sociology, 122(1), 90-124. https://doi.org/10.1086/686941

Kramer, R. (July 2016). Racial Rigidity in the United States: Comment on Saperstein and Penner. American Journal of Sociology, 122(1), 233-246. https://doi.org/10.1086/687374

Kreager, D. A., Jacob, T. N., Young, D. L., Haynie, D. R., Schaefer, M. B., \& Kimberly, M. D. 
(October 2020). In the eye of the beholder: Meaning and structure of informal status in women's and men's prisons. Criminology, 59(1), 42-72. https://doi.org/10.1111/1745-9125.12260

Krohn, M. D. (November 2012). Toward a Unified Criminology: Integrating Assumptions about Crime, People, and Society by Robert Agnew. American Journal of Sociology, 118(3), 853-854. https://doi.org/10.1086/667581

Kubrin, C. E., Stucky, T. D., \& Marvin, D. K. (2009). Researching Theories of Crime and Deviance. Oxford, England: Oxford University Press Inc.

Lamont, M., \& Virag, M. (2002). The Study of Boundaries in the Social Sciences. Annual Review of Sociology, 28, 167-195. https://doi.org/10.1146/annurev.soc.28.110601.141107

Legewie, J. (September 2016). Racial Profiling and Use of Force in Police Stops: How Local Events Trigger Periods of Increased Discrimination. American Journal of Sociology, 122(2), 379-424. https://doi.org/10.1086/687518

Levi, M. (March 2012). Mafias on the Move: How Organized Crime Conquers New Territories by Federico Varese. American Journal of Sociology, 117(5), 1554-1556. https://doi.org/10.1086/664060

Lewis, K., \& Andrew, P. (2019). Rules of the Game: Exponential Random Graph Models of a Gang Homicide Network. Social Forces, 98(4), 1829-1858. https://doi.org/10.1093/sf/soz106

Lopez-Aguado, P., \& Michael, L. W. (2019). 'I don't bang: I'm just a Blood': Sutating gang identities in their proper place. Theoretical Criminology, 25(1), 107-126. https://doi.org/10.1177/1362480619854152

Matsueda, R. L. (September 2011). Divergent Social Worlds: Neighborhood Crime and the Racial-Spatial Divide. American Journal of Sociology, 117(2), 693-696. https://doi.org/10.1086/661750

Mazur, L. B., \& Mariusz, S. (2019). Hidden harmony: Converging interests in the development of prison reform. Theoretical Criminology, 25(1), 149-168. https://doi.org/10.1177/1362480619875732

Menih, H. (September 2020). 'Come Night-time, It's a War Zone': Women's Experiences of Homelessness, Risk and Public Space. The British Journal of Criminology, 60(5), 1136-1154. https://doi.org/10.1093/bjc/azaa018

Messerschmidt, J. W., \& Piers, B. (2015). Criminology: A Sociological Approach. New York, NY: Oxford University Press.

Milkoreit, M. et al. (2018). Defining Tipping Points for Social-Ecological Systems Scholarship-an Interdisciplinary Literature Review. Environmental Research Letters, 13(3), 33005. https://doi.org/10.1088/1748-9326/aaaa75

Mobasseri, S. (June 2019). Race, Place, and Crime: How Violent Crime Events Affect Employment Discrimination. American Journal of Sociology, 125(1), 63-104. 
https://doi.org/10.1086/703883

Monk, E. (2015). The Cost of Color: Skin Color, Discrimination, and Health among African-Americans. American Journal of Sociology, 121(2), 396-444. https://doi.org/10.1086/682162

Muller, C. (September 2012). Northward Migration and the Rise of Racial Disparity in American Incarceration, 1880-1950. American Journal of Sociology, 118(2), 281-326. https://doi.org/10.1086/666384

Muller, C. (September 2018). Freedom and Convict Leasing in the Postbellum South. American Journal of Sociology, 124(3), 367-405. https://doi.org/10.1086/698481

Nordstrom, B. R., \& Charles, A. D. (2011). Drugs and Crime. The Journal of Psychiatry \& Law, 39(4), 663-687, https://doi.org/10.1177/009318531103900407

Nurse, A. (July 2014). Breaking Women: Gender, Race, and the New Politics of Imprisonment. By Jill A. McCorkel. New York: New York University Press, 2013. Pp. $\mathrm{xvi}+272$. \$75.00 (cloth); \$23.00. American Journal of Sociology, 120(1), 293-295. https://doi.org/10.1086/677134

Ocampo, A. C. (September 2011). Hidden Truth: Navigating Lives In and Out of Juvenile Prison by Adam D. Reich. American Journal of Sociology, 117(2), 698-701. https://doi.org/10.1086/661745

Omori, M., \& Nick, P. (September 2020). Institutionalizing inequality in the courts: Decomposing racial and ethnic disparities in detention, conviction, and sentencing. Criminology, 58(4), 678-713. https://doi.org/10.1111/1745-9125.12257

Papachristos, A. V., \& Sara, B. (September 2018). Connected in Crime: The Enduring Effect of Neighborhood Networks on the Spatial Patterning of Violence. American Journal of Sociology, 124(3), 517-568. https://doi.org/10.1086/699217

Phelps, M. S. (September 2018). Discourses of Mass Probation: From Managing Risk to Ending Human Warehousing in Michigan. The British Journal of Criminology, 58(5), 1107-1126. https://doi.org/10.1093/bjc/azx077

Reich, A. D., \& Seth, J. P. (March 2020). The Disciplining Effect of Mass Incarceration on Labor Organization. American Journal of Sociology, 125(5), 1303-1344. https://doi.org/10.1086/709016

Rennison, C. M., \& Mary, D. (2016). Introduction to Criminal Justice: Systems, Diversity, and Change. Thousand Oaks, CA: SAGE Publications.

Rosenfeld, R. (November 2011). The Illusion of Free Markets: Punishment and the Myth of Natural Order by Bernard E. Harcourt. American Journal of Sociology, 117(3), 986-988. https://doi.org/10.1086/662200

Savelsberg, J., Cleveland, L., \& Ryan, K. (2004). Institutional Environments and Scholarly Work: American Criminology, 1951-1993. Social Forces, 82(4), 1275-1302. 
https://doi.org/10.1353/sof.2004.0093

Savelsberg, J. J. (March 2017). The Crime of All Crimes: Toward a Criminology of Genocide. By Nicole Rafter. American Journal of Sociology, 122(5), 1595-1597. https://doi.org/10.1086/690102

Schmalleger, F. (2017). Criminology Today: An Integrative Introduction. New York, NY: Pearson Education Inc.

Schram, P. J., \& Stephen, G. T. (2018). Introduction to Criminology: Why Do They Do It? Thousand Oaks, CA: SAGE Publications.

Schwarz, O. (2015). The Sound of Stigmatization: Sonic Habitus, Sonic Styles, and Boundary Work in an Urban Slum. American Journal of Sociology, 121(1), 205-242. https://doi.org/10.1086/682023

Sharkey, P., Gerard, T.-E., \& Delaram, T. (2017). Community and the Crime Decline: The Causal Effect of Local Nonprofits on Violent Crime. American Sociological Review. https://doi.org/10.1177/0003122417736289

Siegle, L. J. (2015). Criminology: Theories, Patterns and Typologies. Belmont, CA: Wadsworth Publishing.

Siegle, L. J. (2019). Criminology: The Core. Boston, MA: Cengage Learning, Inc.

Slade, G. (September 2018). The Politics of Bureaucratic Corruption in Post-Transitional Eastern Europe by Marina Zaloznaya. American Journal of Sociology, 124(3), 605-607. https://doi.org/10.1086/699357

Sohoni, T., \& Melissa, R. (2019). The whiteness of white-collar crime in the United States: Examining the role of race in a culture of elite white-collar offending. Theoretical Criminology, 25(1), 66-87. https://doi.org/10.1177/1362480619864312

Soliman, F. (2019). States of exception, human rights, and social harm: Towards a border zemiology. Theoretical Criminology, 25(2), 228-248. https://doi.org/10.1177/1362480619890069

Sugie, N. F. (March 2018). Work as Foraging: A Smartphone Study of Job Search and Employment after Prison. American Journal of Sociology, 123(5), 1453-1491. https://doi.org/10.1086/696209

Sweeny, B. N. (September 2014). Party School: Crime, Campus, and Community. By Karen G. Weiss. Boston: Northeastern University Press, 2013. Pp. xxviii+226. $\$ 85.00$ (cloth); $\$ 35.00$ (paper). American Journal of Sociology, 120(2), 615-617. https://doi.org/10.1086/678211

Sykes, B. L. (May 2019). Trapped in a Vice: The Consequences of Confinement for Young People. By Alexandra Cox. New Brunswick, N.J.: Rutgers University Press, 2018. Pp. 234. $\$ 28.95$ (paper). American Journal of Sociology, 124(6), 1938-1940. https://doi.org/10.1086/704034 


\section{Ml Macrothink}

International Journal of Social Science Research

ISSN 2327-5510

2022, Vol. 10, No. 1

Thorneycroft, R., \& Nicole, L. A. (2019). Cripping Criminology. Theoretical Criminology, 25(2), 187-208. https://doi.org/10.1177/1362480619877697

Tran, R.-C., \& Claire, S. (2019). Criminalized Vietnamese women, 'problem gambling' and experiential rifts: Towards a criminology of diversity. Theoretical Criminology, 25(1), 23-43. https://doi.org/10.1177/1362480619869925

Ullrich, L. (2019). 'But what about men?' Gender disquiet in international criminal justice. Theoretical Criminology, 25(2), 209-227. https://doi.org/10.1177/1362480619887164

Vogel, M., Thompson, K., \& Steven, M. (2019). The Enduring Influence of Cohort Characteristics on Race-Specific Homicide Rates. Social Forces, 99(1), 1-30. https://doi.org/10.1093/sf/soz127

Walker, M. L. (January 2016). Race Making in a Penal Institution. American Journal of Sociology, 121(4), 1051-1078. https://doi.org/10.1086/684033

Warner, C. (November 2014). Trading Democracy for Justice: Criminal Convictions and the Decline of Neighborhood Participation. By Traci R. Burch. Chicago: University of Chicago Press, 2013. Pp. x+253. \$25.00 (paper). American Journal of Sociology, 120(3), 973-975. https://doi.org/10.1086/678491

Washington, R. (July 2014). Comic Book Crime: Truth, Justice, and the American Way. By Nickie D. Phillips and Staci Strobel. New York: New York University Press, 2013. Pp. viii+289. \$75.00 (cloth); \$24.00 (paper). American Journal of Sociology, 120(1), 273-275. https://doi.org/10.1086/677105

Webster, J., \& Richard, T. W. (2002). Analyzing the Past to Prepare for the Future: Writing a Literature Review. MIS Quarterly, 26(2), 13-23.

Weisburd, D. (July 2016). Community Criminology: Fundamentals of Spatial and Temporal Scaling, Ecological Indicators, and Selectivity Bias by Ralph Taylor. American Journal of Sociology, 122(1), 290-292. https://doi.org/10.1086/686801

Westbrook, L. (May 2013). Gender, Heterosexuality, and Youth Violence: The Struggle for Recognition. By James W. Messerschmidt. Lanham, Md.: Rowman \& Littlefield Publishers, 2012. Pp. ix +207 . $\$ 75.00$ (cloth); $\$ 25$ (paper). American Journal of Sociology, 118(6), 1725-1727. https://doi.org/10.1086/669658

Western, B., Anthony, A. B., Jaclyn, D., \& Catherine, S. (March 2015). Stress and Hardship after Prison. American Journal of Sociology, 120(5), 1512-1547. https://doi.org/10.1086/681301

Widdowson, A. O., Carter, H., \& Sonja, E. S. (January 2021). Romantic partners and young adult offending: Considering the role of partner's socioeconomic characteristics. Criminology, 59(1), 158-190. https://doi.org/10.1111/1745-9125.12265

Wildeman, C., \& Lars, H. A. (March 2020). Long-term consequences of being placed in disciplinary $\quad$ segregation. $\quad$ Criminology, 58(3), 423-453. 
https://doi.org/10.1111/1745-9125.12241

Wolfe, S. E., \& Spencer, G. L. (May 2020). The organizational justice effect among criminal justice employees: A meta - analysis. Criminology, 58(4), 619-644. https://doi.org/10.1111/1745-9125.12251

Yenkey, C. B. (November 2018). The Outsider's Advantage: Distrust as a Deterrent to Exploitation. American Journal of Sociology, 124(3), 613-663. https://doi.org/10.1086/700694

Zuberi, T. (Sep. 2011). Against Epistemic Apartheid: W. E. B. Du Bois and the Disciplinary Decadence of Sociology. By Reiland Rabaka. American Journal of Sociology, 117(2), 668-670. https://doi.org/10.1086/661735

\section{Notes}

Note 1. Agnew concludes that behaviors should be within the scope of a unified theory of crime if they are blameworthy harms, condemned by the public, and/or sanctioned by the state. He asserts that human behavior ranges from being fully determined to being agentic. Humans are seen as both socially concerned and self-interested. Both consensus and conflict operate in society, varying at any one time depending on which groups, interests, and the time period are being discussed.

Note 2. Although not particularly common, a few articles have appeared recently that specifically aim to explore and evaluate a theory. The appearance of theoretical school is not simply a matter of constructing a framework, but central to the argument. Their aim is thus theoretical in the truest sense. Thomas et al. examine Beckerian rational choice theory and concepts of risk and reward in the context of serious offenses (Thomas et al., 2020). Shi et al. compare two models of crime salience-- the objectivist and social constructionist models-and essentially conclude that crime salience is most consistent with social constructionist models (Shi et al., 2020). Giordano successfully integrates Sutherland's differential association theory and life-course approaches to show that foundational family relationships remain a source of lifelong learning (Giordano, 2020). Two articles explicitly engaged with labeling theory. Motz et al. apply labeling theory in the context of the juvenile justice system and found that contact with the justice system promotes delinquency in a way that affirms existing theory (Motz et al., 2019). Jacobsen reached similar conclusions in the context of suspensions in public schools (Jacobsen, 2019).

\section{Copyrights}

Copyright for this article is retained by the author(s), with first publication rights granted to the journal.

This is an open-access article distributed under the terms and conditions of the Creative Commons Attribution license (http://creativecommons.org/licenses/by/4.0/). 